\begin{abstract}
Iranica
Abstracta Iranica Revue bibliographique pour le domaine irano-aryen

Volume 32-33 | 2013

Comptes rendus des publications de 2009-2010
\end{abstract}

\title{
Gholam Reza Afkhami. The Life and Times of the Shah
}

\section{Clément Therme}

\section{(2) OpenEdition \\ 1 Journals}

\section{Édition électronique}

URL : http://journals.openedition.org/abstractairanica/40754

DOI : 10.4000/abstractairanica.40754

ISSN : 1961-960X

Éditeur :

CNRS (UMR 7528 Mondes iraniens et indiens), Éditions de l'IFRI

\section{Édition imprimée}

Date de publication : 1 décembre 2013

ISSN : 0240-8910

\section{Référence électronique}

Clément Therme, "Gholam Reza Afkhami. The Life and Times of the Shah », Abstracta Iranica [En ligne], Volume 32-33 | 2013, document 284, mis en ligne le 01 juillet 2016, consulté le 26 septembre 2020. URL : http://journals.openedition.org/abstractairanica/40754 ; DOI : https://doi.org/10.4000/ abstractairanica. 40754

Ce document a été généré automatiquement le 26 septembre 2020.

Tous droits réservés 


\title{
Gholam Reza Afkhami. The Life and Times of the Shah
}

\author{
Clément Therme
}

\section{RÉFÉRENCE}

Gholam Reza Afkhami. The Life and Times of the Shah. Berkeley/Los Angeles/London, University of California Press, 2009, 713 p.

1 En écrivant l'histoire d'un homme, l'A. parvient à définir de nouvelles grilles de lecture pour l'histoire contemporaine de l'Iran. Les sources utilisées sont diverses et tirent leur l'originalité des nombreux entretiens de l'A. avec des personnalités importantes du régime Pahlavī ainsi qu'avec des membres de l'opposition. Ce que ce livre tend à démonter peut se résumer dans cette formule de Sadate, prononcée lors des funérailles du dernier shah d'Iran, en juillet 1980 : « the Shah deserved better than the way he had been treated ». Cette histoire de Moḥammad Reḍā Pahlavī est la première grande biographie de cette personnalité dont l'influence a été déterminante sur le destin du pays. Cet ouvrage historique majeur offre un nouvel éclairage sur le règne de Moḥammad Redā Pahlavĩ. Il permet de comprendre les évolutions politiques internes à la monarchie, le rôle $\mathrm{du}$ shah ainsi que sa vision des évènements historiques régionaux et internationaux. En filagramme de ce récit se trouve la révolution islamique, un évènement historique dont les origines sont indissociables de la faillite politique $\mathrm{du}$ régime Pahlavī. 


\section{AUTEURS}

\section{CLÉMENT THERME}

Paris 